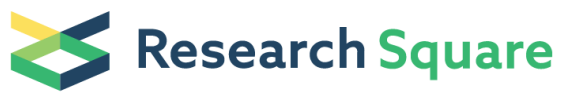 \\ Preprints are preliminary reports that have not undergone peer review. \\ They should not be considered conclusive, used to inform clinical practice, or referenced by the media as validated information.
}

\section{Ozone saline solution counteracts bisphosphonates noxious effects in primary human gingival fibroblasts}

\section{Octavia Iulia Bălean}

Universitatea de Medicina si Farmacie Victor Babes din Timisoara

\section{Alin Daniel Floare}

Universitatea de Medicina si Farmacie Victor Babes din Timisoara

\section{Roxanne Focht}

Universitatea de Medicina si Farmacie Victor Babes din Timisoara

\section{Daniela Jumanca}

Universitatea de Medicina si Farmacie Victor Babes din Timisoara

\section{Dorina Elena Coricovac ( $\boldsymbol{\nabla}$ dorinacoricovac@umft.ro)}

Universitatea de Medicina si Farmacie Victor Babes din Timisoara

https://orcid.org/0000-0002-5760-

8872

\section{Iulia Pinzaru}

Universitatea de Medicina si Farmacie Victor Babes din Timisoara

\section{Cristina Dehelean}

Universitatea de Medicina si Farmacie Victor Babes din Timisoara

\section{Atena Galuscan}

Universitatea de Medicina si Farmacie Victor Babes din Timisoara

\section{Doina Chioran}

Universitatea de Medicina si Farmacie Victor Babes din Timisoara

\section{Angela Codruța Podariu}

Universitatea de Medicina si Farmacie Victor Babes din Timisoara

\section{Research article}

Keywords: bisphosphonates, ozone saline solution, primary human gingival fibroblasts, cell viability, cell morphology.

Posted Date: July 15th, 2019

DOI: https://doi.org/10.21203/rs.2.11340/v1 
License: (c) (i) This work is licensed under a Creative Commons Attribution 4.0 International License. Read Full License 


\section{Abstract}

Background Bisphosphonates are effective antiresorptive agents frequently used in the treatment of different bone disorders, as osteoporosis, Paget's disease and tumours that cause osteolysis. A major concern related to bisphosphonates therapy is represented by osteonecrosis of jaw, a serious, debilitating, and mostly, a therapy-resistant disease, reported as a frequent side effect of bisphosphonates. In the present study were proposed two approaches: 1 ) to verify the impact of four commercially available bisphosphonates, very frequently used as oral (Fosamax - $F$ and Actonel - A) and injectable (Ossica - 0 and Zoledronic acid - Z) therapy on primary human gingival fibroblasts - HGF viability and 2) to evaluate the protective effect of an ozone saline solution on HGF cells pretreated with bisphosphonates. Methods Alamar blue cell viability assay was performed to assess the effect of test compounds $(1.5 ; 2.5 ; 5$ and 10 $\mu \mathrm{M}$ ) on gingival fibroblasts viability after a $24 \mathrm{~h}$ interval. An ozone - 03 saline solution $-80 \mu \mathrm{g} / \mathrm{mL}$ was added to bisphosphonates pretreated fibroblasts for $24 \mathrm{~h}$ and cell viability and cell morphology changes were determined by the means of Alamar blue test and microscopic images. Results Fosamax and Actonel induced a significant reduction of HGF cells viability even at concentrations as low as $2.5 \mu \mathrm{M}(82$ and $79.33 \%$ ) and changes in cells morphology (round and floating cells), effects that were reversed by 03 saline solution administration: an increased cell viability after $F$ and $A$ at $2.5 \mu \mathrm{M}: 147.54$ and 120.11\%), no changes in cells morphology and an improved confluence. Ossica and Zoledronic acid exerted no cytotoxic effect. Conclusions In conclusion, in these experimental conditions, injectable bisphosphonates ( $\mathrm{O}$ and $\mathrm{Z}$ ) proved to be safe for $\mathrm{HGF}$ cells, whereas oral compounds ( $\mathrm{F}$ and $\mathrm{A}$ ) were cytotoxic even at low concentrations, effects that were counteracted by 03 saline solution administration. Based on these data, ozone saline solution might represent a therapeutic alternative for bisphosphonates noxious effects on oral mucosa cells.

\section{Background}

Bisphosphonates are a class of pharmaceutics applied as treatment for several bone disorders and cancers, as: Paget's disease, osteoporosis, multiple myeloma and hypercalcemia of malignancy, that act by suppressing osteoclast differentiation, impairing its activity and leading to early apoptosis. Their activity on osteoclast is also related to adverse events as damaged bone healing and remodeling processes that have as consequence an augmented risk of developing osteonecrosis of jaw, a serious and debilitating condition, in patients subjected to surgical dental procedures as extraction or implant placement $[1,2,3,4,5,6]$. Since more than fifteen years ago, there were raised notable concerns regarding the liaison between the use of bisphosphonates and the increased risk to develop osteonecrosis of the jaw after invasive dental procedures [7]. A considerable number of studies were conceived to find strategies for dental management of patients at risk to develop osteonecrosis of the jaw following antiresorptive (bisphosphonates) and antiangiogenic compounds use [1, 7, 8, 9, 10,11], still, there are no effective therapeutic alternatives to reverse bisphosphonates noxious effects, and to find an appropriate prevention/treatment method for osteonecrosis of the jaw is rather challenging [12]. 
Ozone $\left(\mathrm{O}_{3}\right)$ is an unstable gas, naturally produced by atmospheric air with a triatomic molecule and a reduced half-life ( 40 minutes at $20^{\circ} \mathrm{C}$ ), that exerts multiple biological effects, as: antimicrobial (more efficient as compared to chloride), stimulator of blood circulation and immune response, anti-hypoxic, features that recommend it for medicine and dentistry applications $[13,14,15]$. Among the multiple dental applications of the ozone, there can be stated the following: prevention of dental caries, endodontic treatment, tooth extraction, periodontal pocket disinfection and osseous disinfection, accelerated healing, tissue regeneration, remineralization of tooth surface, teeth whitening, etc $[13,16$, 17]. Moreover, medical ozone formulated as oil suspension or administered as gas insufflations to patients with bisphosphonates-induced osteonecrosis of the jaw lesions proved to be a promising therapeutic option in small ( $<2.5 \mathrm{~cm}-$ oil suspension) and big lesions ( $>2.5 \mathrm{~cm}-$ gas insufflations) [18, 19].

In the light of the data presented above, the present study was subjected: (i) to assess the impact of orally (sodium risedronate - Actonel - A and alendronate - Fosamax - F) and intravenously (ibandronic acid - Ossica - $\mathrm{O}$ and zoledronic acid - Z) bisphosphonates on human primary gingival fibroblasts (HGF) and (ii) to verify if an ozone saline solution counteracts/reverses bisphosphonates noxious effects induced in HGF cells.

\section{Materials And Methods}

\section{Cell line}

The cell line used in the present study was human primary gingival fibroblast - HGF (ATCC $®$ PCS-201$018^{\mathrm{TM}}$ ) purchased from ATCC (American Type Cell Collection) and received as frozen vial. These cells are adherent, bipolar and refractile, present a spindle-shape and were obtained from a Caucasian female.

\section{Reagents}

The culture specific medium - Fibroblast Basal Medium (ATCC PCS-201-030), and Fibroblast growth kit low serum (ATCC PCS-201-041) were acquired from ATCC, whereas the other reagents used, as: trypsin EDTA solution, PBS (phosphate saline buffer), Trypan blue, DMSO (dimethyl sulfoxide), Alamar blue (resazurin sodium salt) were bought from Sigma Aldrich (Germany) and Thermo Fisher Scientific (USA). The test compounds from the class of bisphosphonates: Actonel (risedronic acid - $75 \mathrm{mg}$ tablets, Actavis, Islanda), Fosamax (Alendronate sodium - 70 mg tablets, Merck Sharp \&Dohme, Romania), Ossica (ibandronic acid $-1 \mathrm{mg} / \mathrm{mL}$ solution for i.v administration, Gedeon Richter, Hungary) and Zoledronic acid (Actavis - $4 \mathrm{mg} / 5 \mathrm{~mL}$ solution for parenteral use), were prepared as follows: Actonel and Fosamax were dissolved in DMSO, obtaining stock solutions of $10 \mathrm{mM}$, and Ossica and Zoledronic acid were diluted in culture medium. 


\section{Cell culture}

During the experiment, the cells were grown in specific media - Fibroblast Basal Medium (ATCC PCS-201030), supplemented with Fibroblast growth kit - low serum (ATCC PCS-201-041). HGF cells were maintained in a humidified incubator provided with $5 \% \mathrm{CO}_{2}$ at $37^{\circ} \mathrm{C}$. The cells were numbered using a cell counting device - Countess ${ }^{\mathrm{TM}}$ II Automated Cell Counter (Thermo Fisher Scientific, USA), in the presence of Trypan blue.

\section{Cell viability assessment}

To verify the potential toxicity of the test compounds on human primary gingival fibroblasts - HGF it was applied Alamar blue assay. In brief, HGF cells were seeded in 96-wells plates ( $1 \times 10^{4}$ cells/well/ $\left.200 \mu \mathrm{L}\right)$ and let to grow until the appropriate confluence was reached (24 - $48 \mathrm{~h}$ ). Different concentrations (1.5; 2.5; 5 and $10 \mu \mathrm{M}$ ) of the test compounds (Actonel - A; Fosamax - F; Ossica - O, Zoledronic acid - Z) were added in fresh culture medium and maintained for $24 \mathrm{~h}$ in contact with HGF cells. After $24 \mathrm{~h}$, it was added $20 \mu \mathrm{L}$ of Alamar blue, incubated for $3 \mathrm{~h}$ at $37^{\circ} \mathrm{C}$ and measured the absorbance values at 570 and $600 \mathrm{~nm}$ by the means of $\mathrm{XMark}^{\mathrm{TM}}$ Microplate Spectrophotometer (Biorad).

\section{Ozone impact on human primary gingival fibroblasts}

To determine the effect of ozone $\left(\mathrm{O}_{3}\right.$ saline solution $\left.-80 \mu \mathrm{g} / \mathrm{mL}\right)$ on cells viability and its impact on cells capacity to recover after test compounds toxicity, HGF cells were stimulated with Actonel and Fosamax (compounds that proved to be cytotoxic) $(1.5 ; 2.5 ; 5$ and $10 \mu \mathrm{M})$ for $24 \mathrm{~h}$. The old media was removed, and it was added $100 \mu \mathrm{L}$ of fresh medium and $100 \mu \mathrm{L}$ of ozone saline solution/well for $24 \mathrm{~h}$ according to the protocol described by Perez et al. [20], followed by application of Alamar blue assay, as described above.

\section{Cell morphology}

The effects of test compounds ( $\mathrm{A}, \mathrm{F}, \mathrm{O}$ and $\mathrm{Z}) \pm$ ozone saline solution on cells morphology were assessed by taking pictures before addition of test compounds and after the stimulation period $(24 \mathrm{~h})$. The pictures were acquired by using the Olympus IX73 inverted microscope provided with DP74 camera photo and documented with the CellSens V1.15 software (Olympus, Tokyo, Japan).

\section{Statistical analysis}

The results obtained were expressed as means $\pm S D$, and the difference between means was compared by one-way ANOVA, using the post-hoc Tukey's and Dunnett's multiple comparison tests and by unpaired 
t test with Welch's correction (GraphPad Prism v. 6.0 Software, SUA). The difference between groups was considered statistically significant if $p<0.05$.

\section{Results}

\section{Bisphosphonates decrease human primary gingival fibroblasts - HGF viability}

In the present study, it was evaluated the effect induced by several bisphosphonates (A, F, O and Z) frequently used as treatment for osteoporosis, on HGF cells viability. Stimulation for $24 \mathrm{~h}$ of HGF cells with different compounds from the bisphosphonates family led to distinct results regarding the percentage of viable cells, as follows: $Z$ and $O$ (Figure $1 \mathrm{~A}$ ) had no toxic effects on cells viability, moreover a stimulatory effect was noticed; in the case of $F$ (Figure 1B) it was observed a dose-dependent toxicity, the lowest percentage of viable cells being recorded at $10 \mu \mathrm{M}(67.47 \%$ viable cells), and A (Figure 1B) proved to be toxic even at the lowest concentrations tested (1.5 and $2.5 \mu \mathrm{M}: 77.93 \%$ and $79.33 \%)$, percentage of viable cells that was close to the ones calculated for the highest concentration ( 5 and 10 $\mu \mathrm{M}: 72.37 \%$ and $71.99 \%$ ).

Figure 1. In vitro viability evaluation of Zoledronic acid - Z, Ossica - O, Fosamax - F and Actonel - A $(1.5,2.5,5$ and $10 \mu \mathrm{M})$ on HGF - human primary gingival fibroblasts at $24 \mathrm{~h}$ post-stimulation by Alamar blue assay. The results are expressed as cell viability percentage (\%) normalized to control (for Z and 0 stimulated cells) and to DMSO (for $F$ and A-stimulated cells). The data represent the mean values \pm SD of three independent experiments. One-way ANOVA analysis was applied to determine the statistical differences in rapport with control/DMSO followed by Dunnett's multiple comparisons post-test (** $p<0.01$ and $\left.{ }^{* \star * *} p<0.0001\right)$.

\section{Bisphosphonates impair human primary gingival fibroblasts - HGF morphology}

Since the viability results indicated signs of toxicity after test compounds stimulation ( $F$ and $A$ ), it was verified if there were induced some changes in cells morphology. DMSO was used as vehicle for Actonel and Fosamax. As it can be seen in Figure 2, DMSO-stimulated cells present similar characteristics as control (unstimulated) cells, spindle-shape, bipolar, adherence to the plate, what indicates no toxicity signs induced by different concentrations of DMSO.

Figure 2. The aspect of HGF - human primary gingival fibroblasts in culture: Control - unstimulated cells and cells stimulated with different concentrations of DMSO $(1.5 ; 2.5 ; 5$ and $10 \mu \mathrm{M})$ for $24 \mathrm{~h}$. Pictures were taken using the $20 x$ objective. 
Fosamax stimulation induced several slight changes of HGF cells shape, changes that become more evident with increasing the concentration (Figure 3). Most of the cells kept their spindle shape and their adherence was not affected, still there were also noticed some cells that were round and floating, and cells debris was also present (mainly at 5 and $10 \mu \mathrm{M}$ ), data that are in line with cell viability results.

Figure 3. The aspect of HGF - human primary gingival fibroblasts in culture: Control - unstimulated cells and cells stimulated with different concentrations of Fosamax - $F(1.5 ; 2.5 ; 5$ and $10 \mu \mathrm{M})$ for $24 \mathrm{~h}$.

Pictures were taken using the $20 x$ objective.

Similar results as the ones described for Fosamax were observed in the cells stimulated with Actonel (Figure 4), with the difference that changes in cells shape (round cells), a decreased adherence and the presence of cell debris appeared even at the lowest concentration $(1.5 \mu \mathrm{M})$ tested.

Figure 4. The aspect of HGF - human primary gingival fibroblasts in culture: Control - unstimulated cells and cells stimulated with different concentrations of Actonel - A $(1.5 ; 2.5 ; 5$ and $10 \mu \mathrm{M})$ for $24 \mathrm{~h}$. Pictures were taken using the $20 x$ objective.

In the case of cells stimulated with Zoledronic acid (Figure 5) and Ossica (Figure 6), it was observed a higher confluence of the cells that presented similar shapes with control cells (spindle shape with a high adherence to the plate), data that are in agreement with cell viability findings (Figure 1A).

Figure 5. The aspect of HGF - human primary gingival fibroblasts in culture: Control - unstimulated cells and cells stimulated with different concentrations of Zoledronic acid - Z $(1.5 ; 2.5 ; 5$ and $10 \mu \mathrm{M})$ for $24 \mathrm{~h}$. Pictures were taken using the $20 x$ objective.

Figure 6. The aspect of HGF - human primary gingival fibroblasts in culture: Control - unstimulated cells and cells stimulated with different concentrations of Ossica - $0(1.5 ; 2.5 ; 5$ and $10 \mu \mathrm{M})$ for $24 \mathrm{~h}$. Pictures were taken using the $20 x$ objective.

\section{Ozone suppresses bisphosphonates cytotoxicity on HGF cells}

In this study it was also verified if ozone saline solution can reduce the cytotoxic effects induced by test compounds. For this experiment were chosen only $F$ and $A$, compounds that proved to decrease the percentage of viable cells.

After a $24 \mathrm{~h}$ stimulation with $\mathrm{F}$ and $\mathrm{A}(1.5,2.5,5$ and $10 \mu \mathrm{M})$, the medium was removed and replaced with $100 \mu \mathrm{L}$ new medium $+100 \mu \mathrm{L}$ ozone saline solution $(80 \mu \mathrm{g} / \mathrm{mL}) /$ well for other $24 \mathrm{~h}$. The impact of test compounds stimulation followed by ozone administration was evaluated by the means of Alamar blue assay. 
As it can be seen in Figure 7A, stimulation with ozone $\left(\mathrm{O}_{3}\right)$ solution led to a significant increase of cells viability percentage. Similar results were observed in the case of the cells stimulated with DMSO (data not shown). The images presented in Figure 7B confirm the viability results since the cells that were in contact with $\mathrm{O}_{3}$ solution show a higher confluence, no presence of round and floating cells, what indicates a beneficial effect of ozone on human primary gingival fibroblasts growth and proliferation.

Figure 7. Impact of ozone $\left(\mathrm{O}_{3}\right)$ saline solution on HGF- human primary gingival fibroblasts: A. viability assessment and $\mathrm{B}$. morphology after stimulation with $\mathrm{O}_{3}$ solution for $24 \mathrm{~h}$. Data obtained for viability test (A) represent the mean values \pm SD of three independent experiments. Unpaired $t$ test with Welch's correction was applied to determine the statistical differences in rapport with control cells ( ${ }^{\star \star \star \star} p$ $<0.0001)$.

A significant augmentation of the viable cells percentages was also noticed in the cells stimulated with test compounds $\mathrm{F}$ and $\mathrm{A}$ followed by $\mathrm{O}_{3}$ solution addition for $24 \mathrm{~h}$ as compared to the ones that did not received $\mathrm{O}_{3}$ solution (Figure 8 ). These results show that $\mathrm{O}_{3}$ solution, not only suppressed the toxic effects of test compounds ( $\mathrm{F}$ and $\mathrm{A}$ ), but also improved their capacity to recover and stimulated their growth and proliferation.

Figure 8. Assessment of ozone $\left(\mathrm{O}_{3}\right)$ solution on HGF - human primary gingival fibroblasts viability stimulated previously with Fosamax $-F$ and Actonel $-A(1.5,2.5,5$ and $10 \mu \mathrm{M})$. Data represent the mean values $\pm S D$ of three independent experiments. Unpaired t test with Welch's correction was applied to determine the statistical differences in rapport with $\mathrm{O}_{3}$ unstimulated cells $\left({ }^{* *} \mathrm{p}<0.01,{ }^{* \star *} \mathrm{p}<0.001\right.$ and $\star \star \star * ~ p<0.0001)$.

Ozone $\left(\mathrm{O}_{3}\right)$ solution determined several changes in the morphology of HGF cells stimulated with $\mathrm{F}$ and $\mathrm{A}$ (see Figures 9 and 10), as follows: the cells present spindle and elongated shapes as the control cell, are very adherent to the cell culture plate, their confluence is higher as compared to - $\mathrm{O}_{3}$ group and there were no floating cells or debris within the culture plate.

Figure 9. The aspect of HGF - human primary gingival fibroblasts in culture stimulated with different concentrations of Fosamax $-\mathrm{F}(1.5 ; 2.5 ; 5$ and $10 \mu \mathrm{M})$ for $24 \mathrm{~h}$ : without $\left(-\mathrm{O}_{3}\right)$ and with $\left(+\mathrm{O}_{3}\right)$ ozone stimulation. Pictures were taken using the $20 x$ objective at a scale bar of $50 \mu \mathrm{m}$.

Figure 10. The aspect of HGF - human primary gingival fibroblasts in culture stimulated with different concentrations of Actonel $-\mathrm{A}(1.5 ; 2.5 ; 5$ and $10 \mu \mathrm{M})$ for $24 \mathrm{~h}$ : without $\left(-\mathrm{O}_{3}\right)$ and with $\left(+\mathrm{O}_{3}\right)$ ozone stimulation. Pictures were taken using the $20 x$ objective at a scale bar of $50 \mu \mathrm{m}$.

\section{Discussions}

Bisphosphonates are synthetic analogues of pyrophosphates known to strongly bind to hydroxyapatite (a mineral from bone structure) and modify bone resorption by decreasing bone metabolism and 
remodeling processes [7]. There were described two different classes of bisphosphonates: non-nitrogen (risedronate) and nitrogen containing (alendronate, ibandonic acid and zoledronic acid)

bisphosphonates, that present a disparate mechanism of action, as follows: non-nitrogen compounds are taken up by the osteoclast and metabolized to adenosine triphosphate analogues with noxious effects that induce osteoclast apoptosis or cell death, whereas nitrogen containing bisphosphonates are interiorized by osteoclasts during resorption process and impair the mevalonate pathway (involved in the synthesis of cholesterol) leading to suppression of bone resorption [21]. The side effects of bisphosphonates include irritation of the oesophagus, dysphagia, migraines, intestinal obstruction, joint and bone pain, but most importantly osteonecrosis of the jaws - a main dental adverse event $[3,5,10,11]$. Osteonecrosis of the jaw has become a major concern in the field of dentistry, since the risk of development to patients under the treatment with these agents that suffer invasive dental procedures is quite elevated and treating this kind of patients requires a complex management of the pathology. The most cases of osteonecrosis of jaw were recorded after administration of orally bisphosphonates alendronate (the most frequently used worldwide) [2].

Taking into consideration that the category of patients that use bisphosphonates therapy becomes wider day by day (approximatively 75 million people are affected by osteoporosis in Europe, U.S. and Japan) [22], it is important to know the impact of these compounds in the organism, especially, since this kind of medication is for long-term.

In this study, it was verified the effect of several types of bisphosphonates (Fosamax - F, Actonel -A, Ossica - $\mathrm{O}$ and Zoledronic acid - Z) on human primary gingival fibroblasts - HGF viability and morphology after a $24 \mathrm{~h}$ stimulation.

Human primary gingival fibroblasts were selected for this study based on the following considerations: (i) these cells are the main constituents of the gingival connective tissue and the most abundant residents of oral mucosa; (ii) play key roles in scarless wound healing process by releasing multiple growth factors (transforming growth factor beta - TGF-Beta, connective tissue growth factor - CTGF, and basic fibroblast growth factor - bFGF); and iii) primary cells offer more reliable data as compared to immortalized cell lines $[23,24]$. In addition, previous studies proved that primary human gingival fibroblasts are valuable and reliable in vitro models for screening toxicity/cytocompatibility of dental materials $[23,25,26]$.

Our results showed that $F$ and $A$ become cytotoxic even at low concentrations as $1.5 \mu \mathrm{M}$ (see Figure 1B) and also cells morphology was altered (see Figures 3 and 4), whereas $O$ and $Z$ had no cytotoxic effects at the concentrations tested $(1.5 ; 2.5 ; 5$ and $10 \mu \mathrm{M}$ ) (see Figure 1A). The cytotoxic effect of alendronate $-\mathrm{F}$ on human primary gingival fibroblasts was also shown by other groups of research [27, 28, 29], data that are in agreement with these results. Stimulation of human stem cells derived from the gingiva with risedronate in the range of $1-10 \mu \mathrm{M}$ led to changes in cells morphology and a reduced viability [30], findings that confirm our results.

An in vitro study developed on human umbilical cord vein endothelial cells (HUVEC), human gingival fibroblasts (HGF), human osteogenic cells (HHOB-c) and human oral keratinocytes (HOK) stimulated with 
$50 \mu \mathrm{M}$ ibandronate, pamidronate or zoledronate for $24 \mathrm{~h}$ showed that bisphosphonates used reduced all cells viability [31]. The results obtained in the present study showed that $Z$ (zoledronic acid) and 0 (ibandronic acid) are not cytotoxic for primary gingival fibroblasts at concentrations $\leq 10 \mu \mathrm{M}$.

Another study conducted by Soydan et al. [28] demonstrated the toxic effects of Alendronate (Fosamax) and PAM (pamidronate) on human gingival fibroblasts, characterized by significant changes in the apoptotic and proliferative indices leading to an in vitro faulty epithelisation of the oral mucosa. The change of these indices is an important factor in the management of delayed healing of the oral mucosa, secondary to surgery in patients under bisphosphonate treatment, and is a problem that reduces the success rate of healing in cases of bisphosphonate-induced maxillary osteonecrosis [14, 32].

Looking for new ways to reduce the side effects of bisphosphonates, ozone was described as a viable choice for healing and restoring oral cells viability. Besides the benefits of ozone in dentistry (carious lesions treatment, endodontics, reduction of dental hypersensitivity, periodontics, oral surgery, pedodontics, orthodontics) $[15,17]$, were also mentioned other biological effects, as: (a) antimicrobial activity against aerobic and anaerobic bacteria (especially Staphylococcus aureus), fungi and viruses; (b) stimulator of the circulatory system, increasing haemoglobin synthesis and the production of red blood cells, thereby producing tissue oxygenation; (c) modulator of immune cells, acting as a cytokine, and increasing their phagocytosis and diapedesis; (d) stimulator of angiogenesis as well as the proliferation of fibroblasts; and (e) pain reduction capacity $[15,33]$.

Addition of the ozone saline solution (stock concentration - $\mathrm{O}_{3}$ saline solution $-80 \mu \mathrm{g} / \mathrm{mL} ; 100 \mu \mathrm{L} /$ well) to pretreated HGF cells with $\mathrm{F}$ and $\mathrm{A}$ for $24 \mathrm{~h}$ led to an increase of cells viable percentages as compared to the ones stimulated only with $\mathrm{F}$ and $\mathrm{A}$ (see Figure 8 ) and it was also noticed an improvement of cells confluence and a cells morphology similar to the control ones (unstimulated cells) (see Figures 9 and 10), what demonstrates that ozone solution in these experimental conditions was able to reverse the toxic effects induced by $F$ and $A$. Our data are in line with other data from the literature that confirm the protective effects of ozone on gingival fibroblasts [32, 34, 35].

Moreover, daily application of an ozonated water treatment accelerated the rate of physiological healing. In a study comparing the use of ozonated oil in an experimental group with a control group using antibiotic therapy in the treatment of alveolitis, it was found that patients treated with ozonated oil healed more quickly [36,37]. Ozone was also used in the treatment of avascular osteonecrosis of the maxilla $(\mathrm{ONJ})$. Complete healing of lesions with disappearance of symptoms has been noticed [38, 39].

\section{Conclusions}

In the view of these findings, it could be stated that oral bisphosphonates - Fosamax and Actonel exert a concentration-dependent toxicity on human primary gingival fibroblasts by decreasing the percentage of viable cells and modifying cells morphology. In contrast, injectable bisphosphonates - Zoledronic acid and Ossica did not affect the viability or HGF cells morphology. Ozone saline solution administration to

Page $10 / 22$ 
bisphosphonates - treated cells reversed the toxic effects of test compounds ( $F$ and $A$ ) and improved cells capacity to recover by stimulating their growth and proliferation. These in vitro results represent a valuable background that endorse the hypothesis that ozone saline solution could be considered a therapeutic alternative for bisphosphonates noxious effects on oral mucosa cells.

\section{List Of Abbreviations}

A - Actonel

ATCC - American Type Cell Collection

bFGF - basic fibroblast growth factor

CTGF - connective tissue growth factor

DMSO - dimethyl sulfoxide

EDTA - Ethylenediaminetetraacetic acid

F - Fosamax

HGF - primary human gingival fibroblasts

HHOB-c - human osteogenic cells

HOK - human oral keratinocytes

HUVEC - human umbilical cord vein endothelial cell

i.v. - intravenous

O-Ossica

$\mathrm{O}_{3}-$ ozone

ONJ - osteonecrosis of the jaw

PAM - pamidronate

PBS - phosphate saline buffer

TGF-Beta - transforming growth factor beta

Z - Zoledronic acid

\section{Declarations}




\section{Ethics approval and consent to participate}

Not applicable.

\section{Consent for publication}

Not applicable.

\section{Availability of data and materials}

The datasets used and/or analyzed during the current study are available from the corresponding author on reasonable request.

\section{Conflict of interest}

The authors declare that they have no competing interests.

\section{Authors' contributions}

OIB, AG, ACP concepted and designed the study, contributed to the interpretation of data, drafting the article and revising it critically. DC, IP, CD were responsible with acquisition of data, analysis and interpretation of data and critically revision of the manuscript. ADF, RF, DJ, DC contributed to the design of the study and by revising critically the manuscript. The final form of the manuscript was read and received the approval of all the authors.

\section{Acknowledgements}

Not applicable.

\section{References}

1. Malden N, Beltes C, Lopes V. Dental extractions and bisphosphonates: the assessment, consent and management, a proposed algorithm. Br Dent J. 2009; 206(2):93-8. doi: 10.1038/sj.bdj.2009.5.

2. Kalra S, Jain V. Dental complications and management of patients on bisphosphonate therapy: A review article. J Oral Biol Craniofac Res. 2013; 3(1):25-30. doi: 10.1016/j.jobcr.2012.11.001.

3. Kühl S, Walter C, Acham S, Pfeffer R, Lambrecht JT. Bisphosphonate-related osteonecrosis of the jaws - A review. Oral Oncology. 2012; 48(10):938-947. doi:10.1016/j.oraloncology.2012.03.028.

4. Coskun Benlidayi I, Guzel R. Oral Bisphosphonate Related Osteonecrosis of the Jaw: A Challenging Adverse Effect. ISRN Rheumatology, 2013; 1-6. doi:10.1155/2013/215034. 
5. Watts NB, Diab DL. Long-Term Use of Bisphosphonates in Osteoporosis. J Clin Endocrinol Metab. 2010; 95(4):1555-1565. doi:10.1210/jc.2009-1947.

6. Coleman RE, McCloskey EV. Bisphosphonates in oncology. Bone. 2011; 49(1):71-76. doi:10.1016/j.bone.2011.02.003.

7. Di Fede O, Panzarella V, Mauceri R, Fusco V, Bedogni A, Lo Muzio L, Sipmo Onj Board, Campisi G. The Dental Management of Patients at Risk of Medication-Related Osteonecrosis of the Jaw: New Paradigm of Primary Prevention. Biomed Res Int. 2018; 2018:2684924. doi: 10.1155/2018/2684924.

8. Khan AA, Morrison A, Hanley DA, et al. Diagnosis and management of osteonecrosis of the jaw: a systematic review and international consensus. J Bone Miner Res. 2015; 30(1):3-23. doi:

10.1002/jbmr.2405.

9. Coello-Suanzes JA, Rollon-Ugalde V, Castaño-Seiquer A, Lledo-Villar E, Herce-Lopez J, Infante-Cossio $\mathrm{P}$, Rollon-Mayordomo A. Preventive dental management of osteonecrosis of the jaws related to zoledronic acid treatment. Oral Dis. 2018; 24(6):1029-1036. doi: 10.1111/odi.12842.

10. Pozzi S, Raje N. The Role of Bisphosphonates in Multiple Myeloma: Mechanisms, Side Effects, and the Future. The Oncologist. 2011; 16(5):651-662. doi:10.1634/theoncologist.2010-0225.

11. Abrahamsen B. Adverse Effects of Bisphosphonates. Calcif Tissue Int. 2010; 86:421. doi:10.1007/s00223-010-9364-1.

12. Rosella D, Papi P, Giardino R, Cicalini E, Piccoli L, Pompa G. Medication-related osteonecrosis of the jaw: Clinical and practical guidelines. J Int Soc Prev Community Dent. 2016; 6(2):97-104. doi: 10.4103/2231-0762.178742.

13. Saini R. Ozone therapy in dentistry: A strategic review. J Nat Sci Biol Med. 2011; 2(2): 151-153. doi: 10.4103/0976-9668.92318.

14. Tiwari S, Avinash A, Katiyar S, Aarthi lyer A, Jain S. Dental applications of ozone therapy: A review of literature. The Saudi Journal for Dental Research. 2017; 8(1-2):105-111. doi:10.1016/j.sjdr.2016.06.005.

15. Gupta S, Deepa D. Applications of ozone therapy in dentistry. J Oral Res Rev. 2016; 8:86-91. doi: 10.4103/2249-4987.192243.

16. Naik SV, K R, Kohli S, Zohabhasan S, Bhatia S. Ozone - A Biological Therapy in Dentistry - Reality or Myth????? Open Dent J. 2016; 10:196-206. doi: 10.2174/1874210601610010196.

17. Jumanca D, Matichescu A, Galuscan A, Podariu AC, Oancea R, Sava-Rosianu R, Rusu LC. Treatment with ozone before sealing pits and fissures. Medicine in Evolution. 2017; 23(4): 456-462.

18. Ripamonti $\mathrm{Cl}$, Cislaghi E, Mariani L, Maniezzo M. Efficacy and safety of medical ozone (O(3)) delivered in oil suspension applications for the treatment of osteonecrosis of the jaw in patients with bone metastases treated with bisphosphonates: Preliminary results of a phase I-II study. Oral Oncol. 2011; 47(3):185-90. doi: 10.1016/j.oraloncology.2011.01.002

19. Ripamonti Cl, Maniezzo M, Boldini S, Pessi MA, Mariani L, Cislaghi E. Efficacy and tolerability of medical ozone gas insufflations in patients with osteonecrosis of the jaw treated with 
bisphosphonates-Preliminary data: Medical ozone gas insufflation in treating ONJ lesions. J Bone Oncol. 2012;1(3):81-7. doi: 10.1016/j.jbo.2012.08.001.

20. Pérez A, Santos Cuevas CL, Chairez I, Poznyak T, Ordaz-Rosado D, García-Becerra R, Romero Piña ME. Ozone dosage effect on $\mathrm{C} 6$ cell growth, in vitro and in vivo tests: double bond index for characterization. Anal. Methods. 2014; 6:4567-4575.

21. Wang HL, Weber D, McCauley LK. Effect of long-term oral bisphosphonates on implant wound healing: literature review and a case report. J Periodontol. 2007; 78(3):584-94. doi: 10.1902/jop.2007.060239.

22. Global Osteoporosis Treatment Market 2017-2025: Bisphosphonates, Parathyroid Hormone Therapy, Calcitonin, SERM and Rank Ligand Inhibitors. https://www.prnewswire.com/news-releases/globalosteoporosis-treatment-market-2017-2025-bisphosphonates-parathyroid-hormone-therapy-calcitoninserm-and-rank-ligand-inhibitors-300594031.html

23. Soares ASLS, Scelza MZ, Spoladore J, et al. Comparison of primary human gingival fibroblasts from an older and a young donor on the evaluation of cytotoxicity of denture adhesives. J Appl Oral Sci. 2018; 26:e20160594. doi:10.1590/1678-7757-2016-0594.

24. Egusa $\mathrm{H}$, Okita $\mathrm{K}$, Kayashima $\mathrm{H}$, et al. Gingival fibroblasts as a promising source of induced pluripotent stem cells. PLoS One. 2010; 5(9):e12743. doi:10.1371/journal.pone.0012743.

25. Pham MH, Haugen HJ, Rinna A, Ellingsen JE, Reseland JE. Hydrofluoric acid treatment of titanium surfaces enhances the proliferation of human gingival fibroblasts. J Tissue Eng. 2019; 10:2041731419828950. doi:10.1177/2041731419828950.

26. Herráez-Galindo C, Rizo-Gorrita M, Luna-Oliva I, Serrera-Figallo MÁ, Castillo-Oyagüe R, Torres-Lagares D. In vitro Comparative Study of Fibroblastic Behaviour on Polymethacrylate (PMMA) and Lithium Disilicate Polymer Surfaces. Polymers (Basel). 2019; 11(4):744. doi:10.3390/polym11040744.

27. Açil Y, Möller B, Niehoff P, Rachko K, Gassling V, Wiltfang J, Simon MJ. The cytotoxic effects of three different bisphosphonates in-vitro on human gingival fibroblasts, osteoblasts and osteogenic sarcoma cells. J Craniomaxillofac Surg. 2012; 40(8):e229-35. doi: 10.1016/j.jcms.2011.10.024.

28. Soydan SS, Araz K, Senel FV, Yurtcu E, Helvacioglu F, Dagdeviren A, Tekindal MA, Sahin F. Effects of alendronate and pamidronate on apoptosis and cell proliferation in cultured primary human gingival fibroblasts. Hum Exp Toxicol. 2015; 34(11):1073-82. doi: 10.1177/0960327115569808.

29. Açil Y, Arndt ML, Gülses A, Wieker H, Naujokat H, Ayna M, Wiltfang J. Cytotoxic and inflammatory effects of alendronate and zolendronate on human osteoblasts, gingival fibroblasts and osteosarcoma cells. J Craniomaxillofac Surg. 2018; 46(4):538-546. doi: 10.1016/j.jcms.2017.12.015.

30. Kim BB, Ko Y, Park JB. Effects of risedronate on the morphology and viability of gingiva-derived mesenchymal stem cells. Biomed Rep. 2015; 3(6):845-848. doi: 10.3892/br.2015.520.

31. Walter C, Pabst AM, Ziebart T. Effects of a low-level diode laser on oral keratinocytes, oral fibroblasts, endothelial cells and osteoblasts incubated with bisphosphonates: An in vitro study. Biomed Rep. 2015; 3(1):14-18. doi: 10.3892/br.2014.389. 
32. Akdeniz SS, Beyler E, Korkmaz Y, Yurtcu E, Ates U, Araz K, Sahin FI, Torun OY. The effects of ozone application on genotoxic damage and wound healing in bisphosphonate-applied human gingival fibroblast cells. Clin Oral Investig. 2018; 22(2):867-873. doi: 10.1007/s00784-017-2163-6.

33. Kumar A, Bhagawati S, Tyagi P, Kumar P. Current interpretations and scientific rationale of the ozone usage in dentistry: A systematic review of literature. Eur J Gen Dent 2014; 3:175-80.

34. Nogales CG, Ferreira MB, Montemor AF, Rodrigues MF, Lage-Marques JL, Antoniazzi JH. Ozone therapy as an adjuvant for endondontic protocols: microbiological - ex vivo study and citotoxicity analyses. J Appl Oral Sci. 2016; 24(6):607-613. doi: 10.1590/1678-775720160029.

35. Azarpazhooh A, Limeback $H$. The application of ozone in dentistry: a systematic review of literature. J Dent. 2008; 36(2):104-16. doi: 10.1016/j.jdent.2007.11.008.

36. Pattanaik B, Jetwa D, Pattanaik S, Manglekar S, Naitam DN, Dani A. Ozone therapy in dentistry: a literature review. J Interdiscip Dent. 2011; 1(2):87-92.

37. Nogales CG, Ferrari PH, Kantorovich EO, Lage-Marques JL. Ozone therapy in medicine and dentistry. J Contemp Dent Pract. 2008; 9:75-84.

38. Loncar B, Mravak Stipetic M, Matosevic D, Tarle Z. Ozone application in dentistry. Arch Med Res 2009; 40:136-7.

39. Shilpa RA, Reddy N, Dinapadu S, Reddy M, Pasari S. Role of ozone therapy in minimal intervention dentistry and endodontics - A review. J Int Oral Health 2013; 5:102 - 8.

\section{Figures}

A

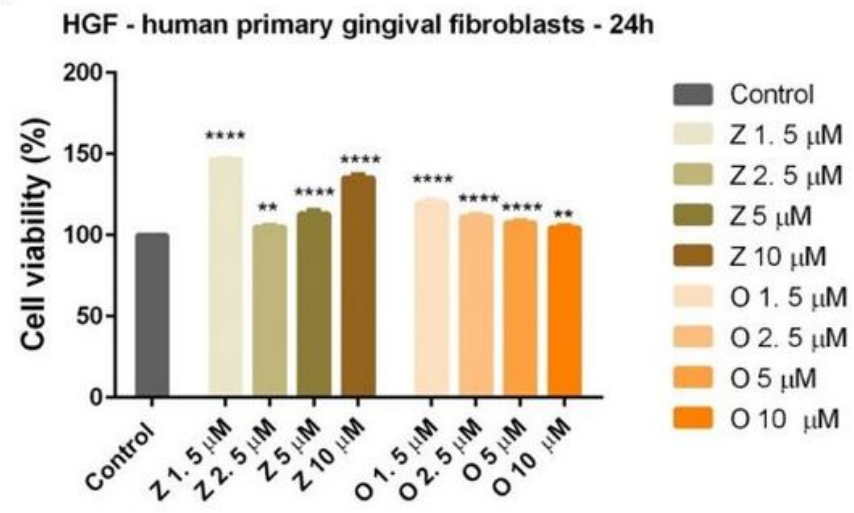

B

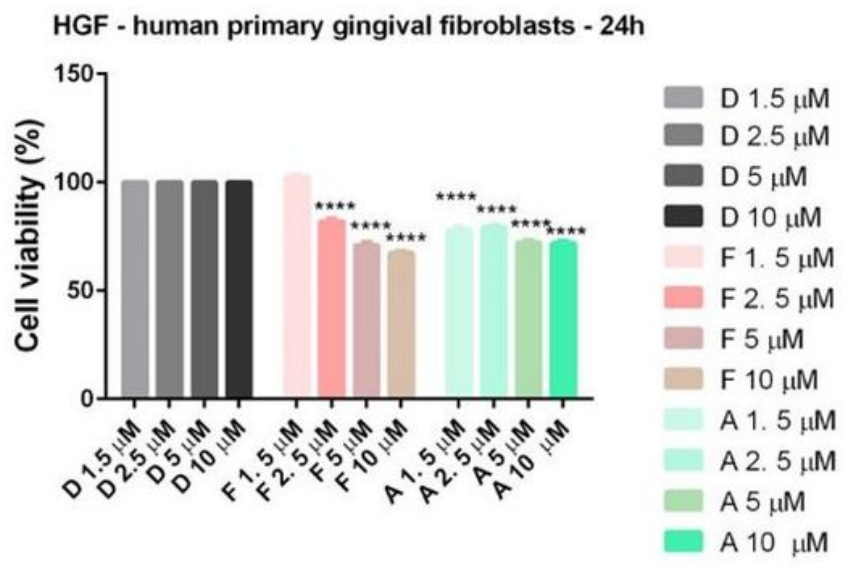

\section{Figure 1}

In vitro viability evaluation of Zoledronic acid - Z, Ossica - O, Fosamax - F and Actonel - A (1.5, 2.5, 5 and $10 \mu \mathrm{M}$ ) on HGF - human primary gingival fibroblasts at $24 \mathrm{~h}$ post-stimulation by Alamar blue assay. The results are expressed as cell viability percentage (\%) normalized to control (for $Z$ and $O$ - stimulated cells) and to DMSO (for F and A-stimulated cells). The data represent the mean values \pm SD of three independent experiments. One-way ANOVA analysis was applied to determine the statistical differences 


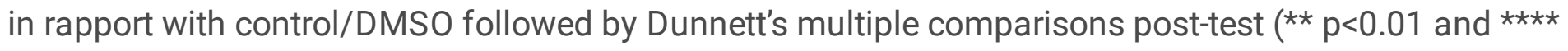
$\mathrm{p}<0.0001)$.

DMSO $1.5 \mu \mathrm{M}$
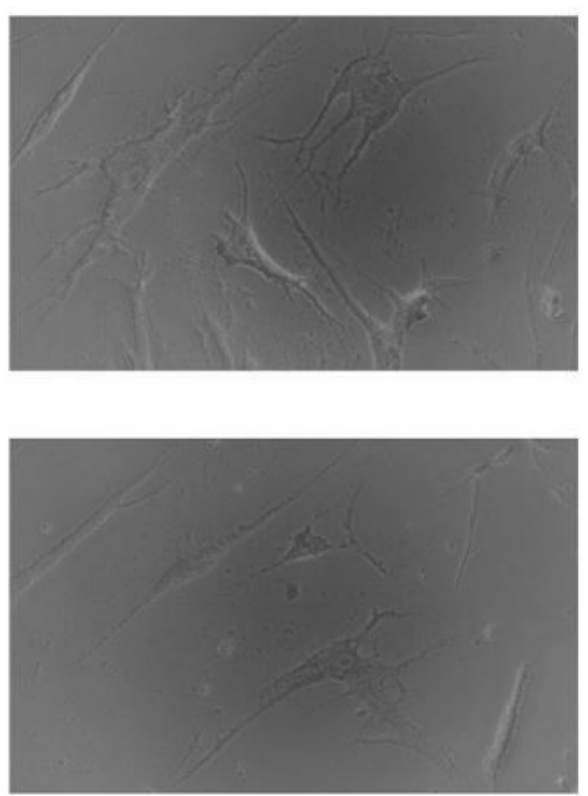

DMSO $5 \mu \mathrm{M}$
DMSO $2.5 \mu \mathrm{M}$
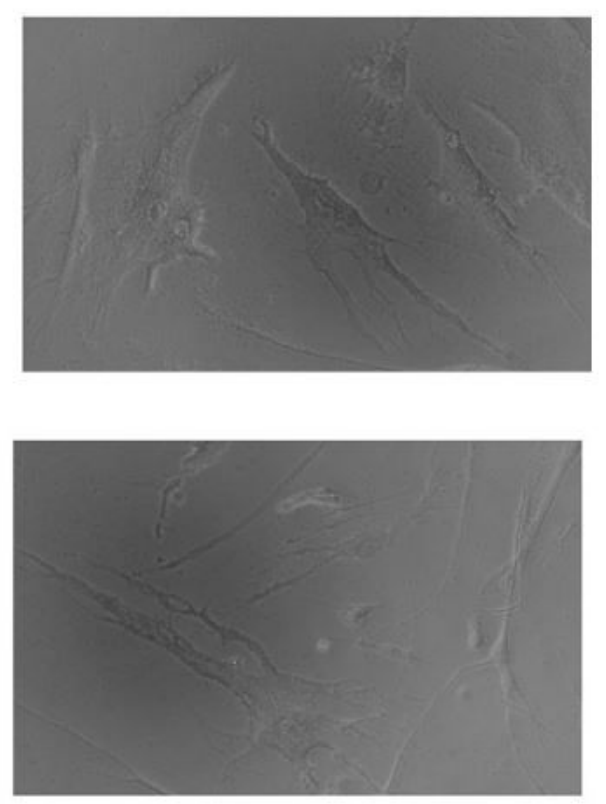

DMSO $10 \mu \mathrm{M}$

\section{Figure 2}

The aspect of HGF - human primary gingival fibroblasts in culture: Control - unstimulated cells and cells stimulated with different concentrations of DMSO $(1.5 ; 2.5 ; 5$ and $10 \mu \mathrm{M})$ for $24 \mathrm{~h}$. Pictures were taken using the $20 x$ objective.

$\mathrm{F} 1.5 \mu \mathrm{M}$
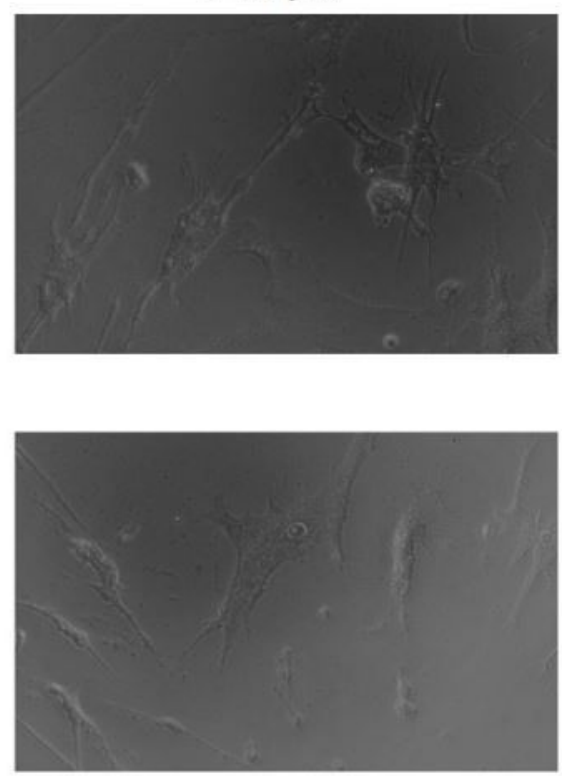

$\mathrm{F} 5 \mu \mathrm{M}$
F $2.5 \mu \mathrm{M}$
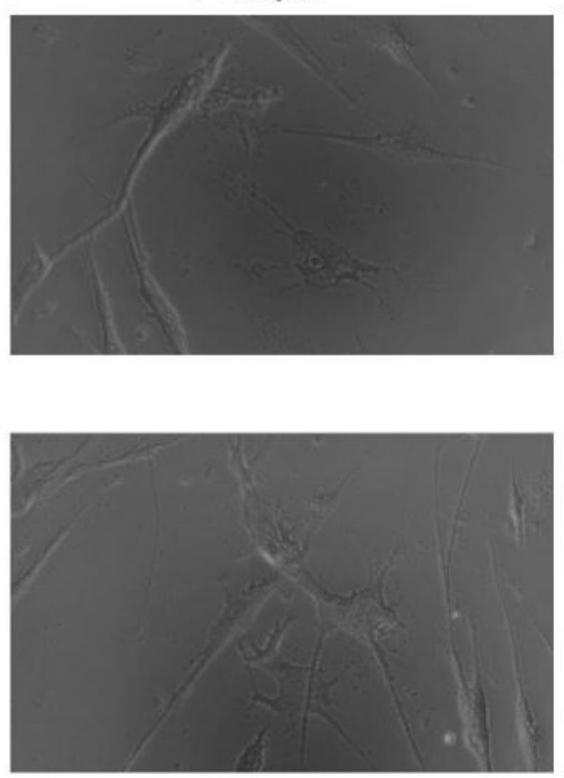

$\mathrm{F} 10 \mu \mathrm{M}$ 


\section{Figure 3}

The aspect of HGF - human primary gingival fibroblasts in culture: Control - unstimulated cells and cells stimulated with different concentrations of Fosamax - F $(1.5 ; 2.5 ; 5$ and $10 \mu \mathrm{M})$ for $24 \mathrm{~h}$. Pictures were taken using the $20 x$ objective.

A $1.5 \mu \mathrm{M}$
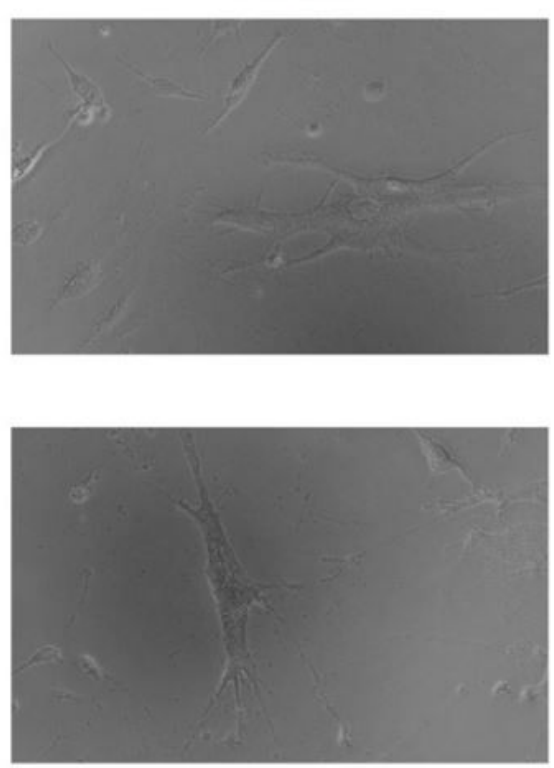

A $5 \mu \mathrm{M}$
A $2.5 \mu \mathrm{M}$
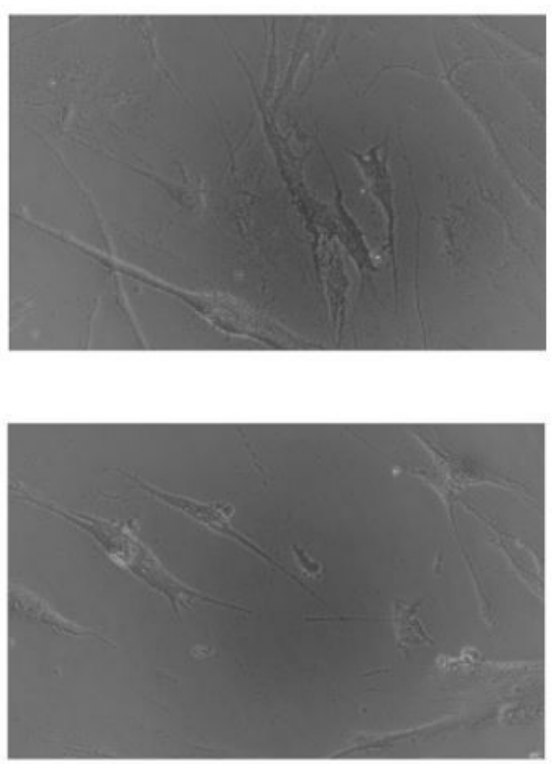

$\mathrm{A} 10 \mu \mathrm{M}$

\section{Figure 4}

The aspect of HGF - human primary gingival fibroblasts in culture: Control - unstimulated cells and cells stimulated with different concentrations of Actonel - A $(1.5 ; 2.5 ; 5$ and $10 \mu \mathrm{M})$ for $24 \mathrm{~h}$. Pictures were taken using the $20 x$ objective. 
$\mathrm{Z} 1.5 \mu \mathrm{M}$

\section{Control}

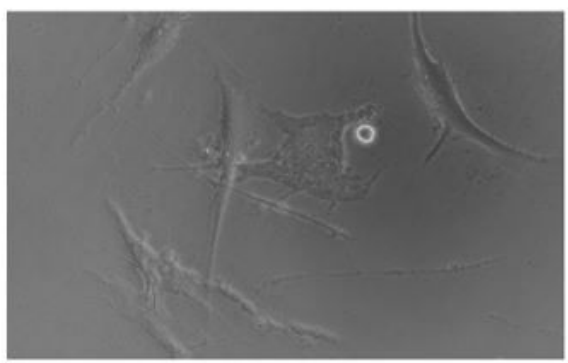

$\mathrm{Z} 2.5 \mu \mathrm{M}$
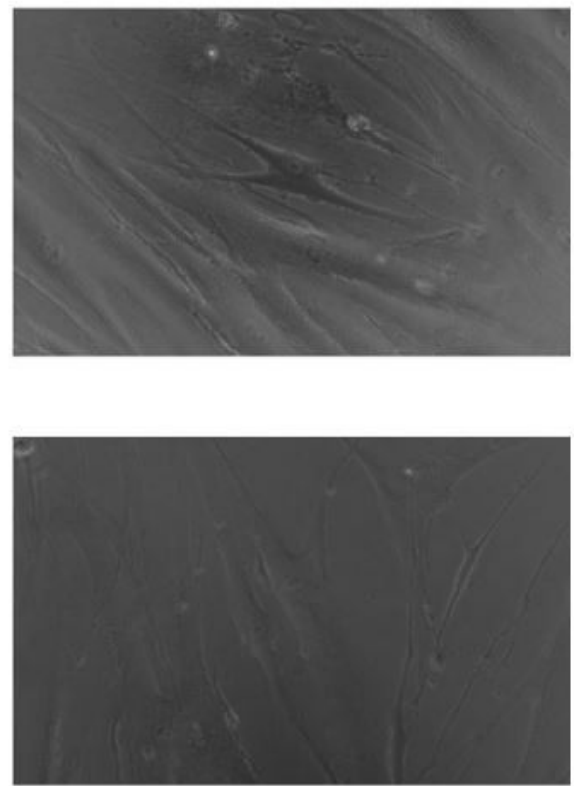

$\mathrm{Z} 10 \mu \mathrm{M}$

\section{Figure 5}

The aspect of HGF - human primary gingival fibroblasts in culture: Control - unstimulated cells and cells stimulated with different concentrations of Zoledronic acid - Z $(1.5 ; 2.5 ; 5$ and $10 \mu \mathrm{M})$ for $24 \mathrm{~h}$. Pictures were taken using the $20 x$ objective.

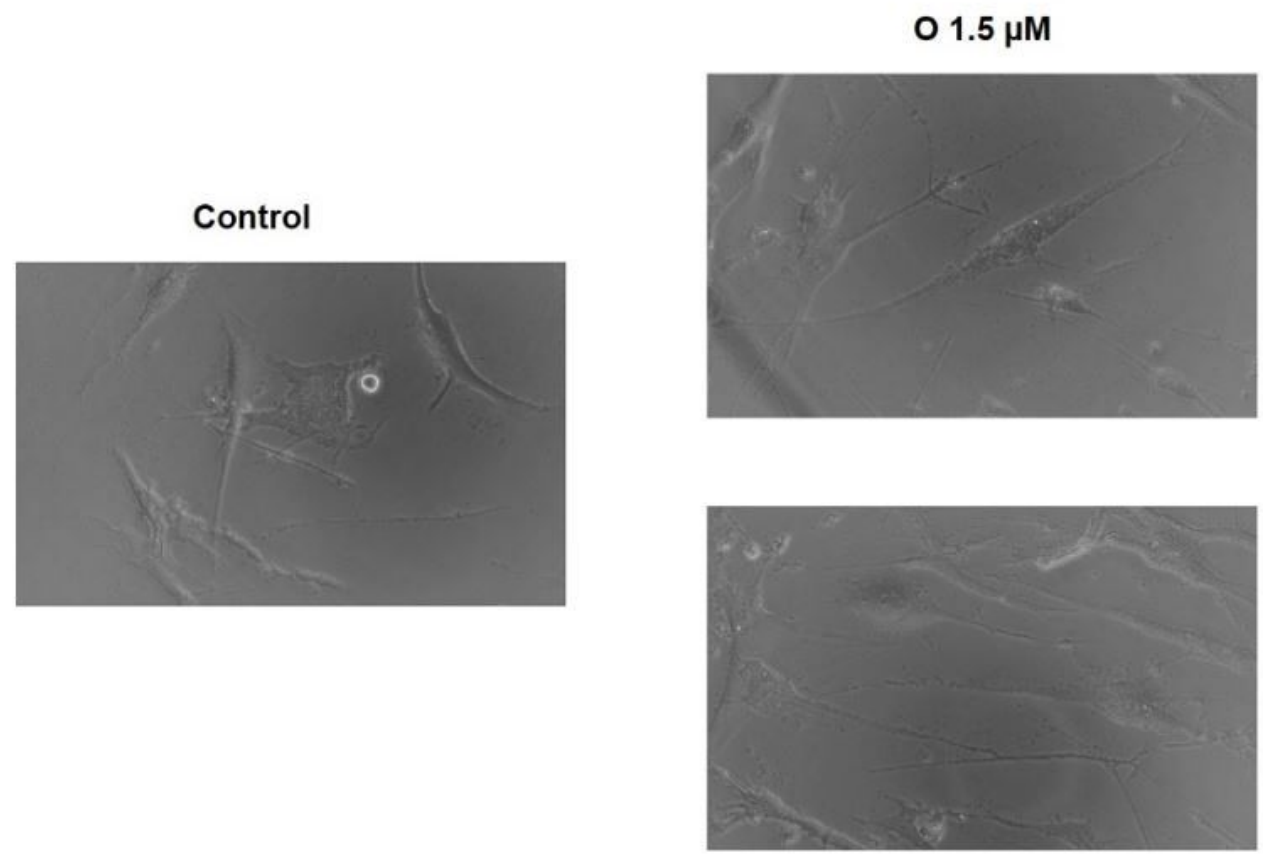

$05 \mu \mathrm{M}$
$02.5 \mu \mathrm{M}$
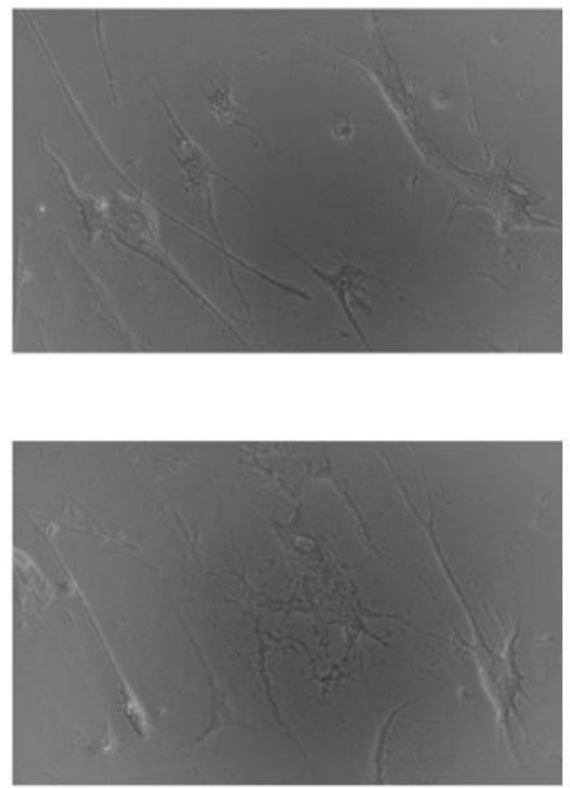

$010 \mu \mathrm{M}$

Figure 6 
The aspect of HGF - human primary gingival fibroblasts in culture: Control - unstimulated cells and cells stimulated with different concentrations of Ossica - $\mathrm{O}(1.5 ; 2.5 ; 5$ and $10 \mu \mathrm{M})$ for $24 \mathrm{~h}$. Pictures were taken using the $20 x$ objective.

$-\mathrm{O}_{3}$

B

A

HGF - human primary gingival fibroblasts - $24 \mathrm{~h}$

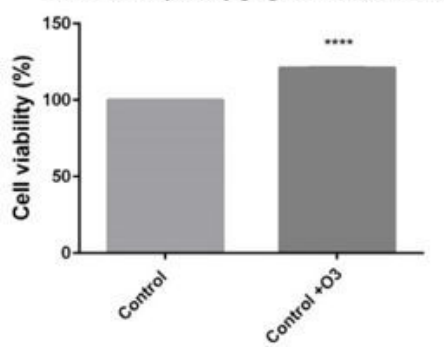

Control

- Control $+\mathrm{O} 3$
Control
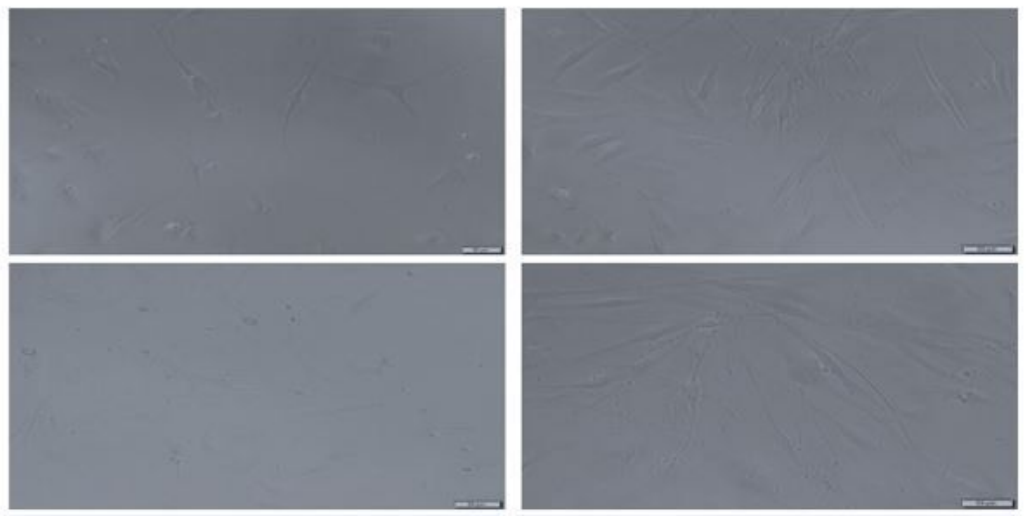

DMSO $2.5 \mu \mathrm{M}$

DMSO $5 \mu \mathrm{M}$

DMSO $10 \mu \mathrm{M}$
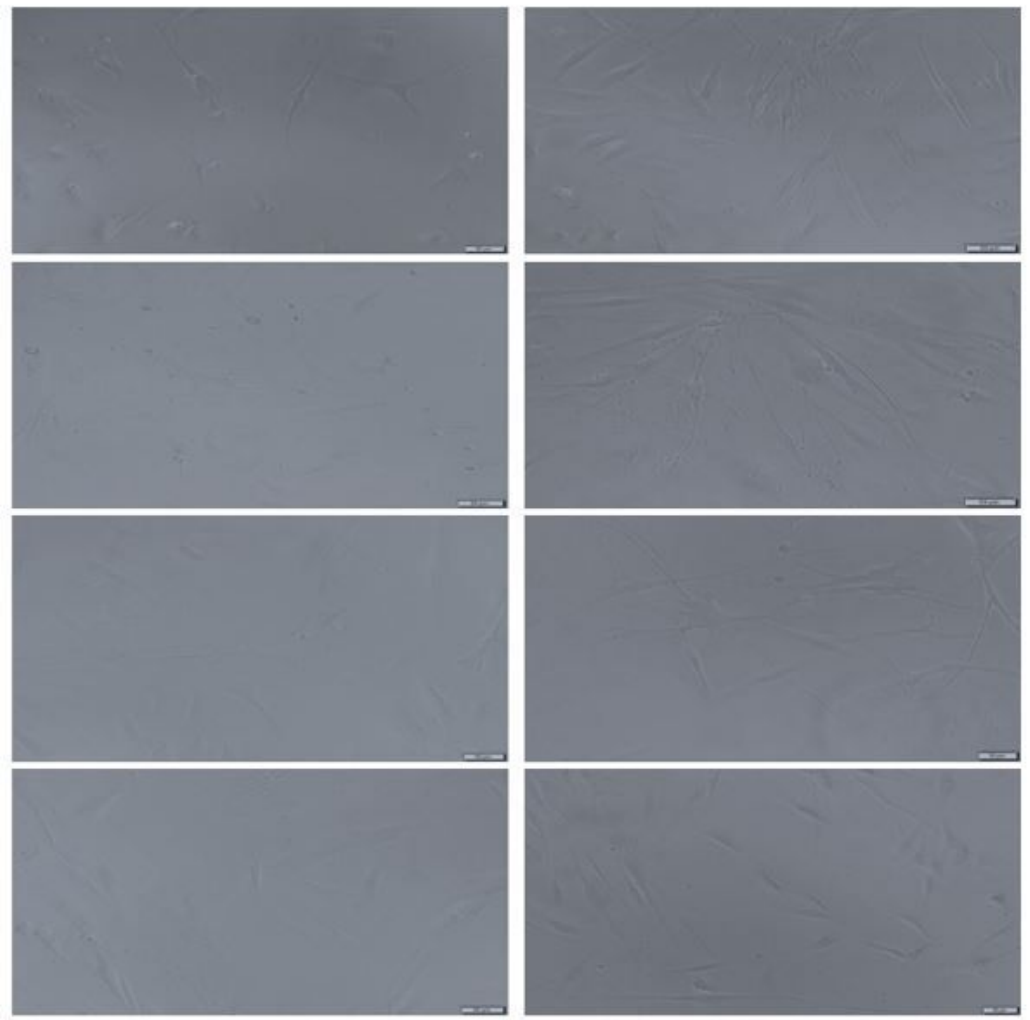
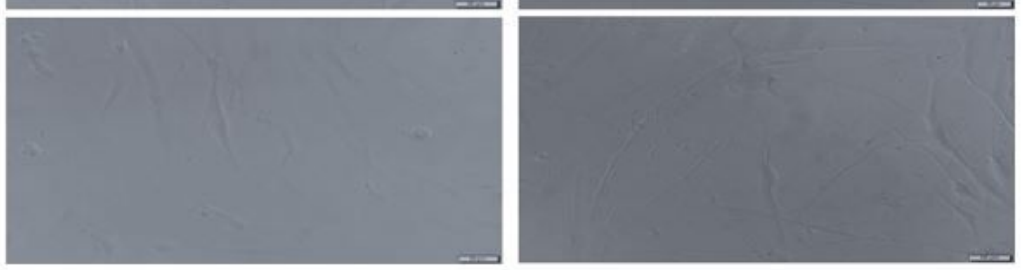

\section{Figure 7}

The aspect of HGF - human primary gingival fibroblasts in culture: Control - unstimulated cells and cells stimulated with different concentrations of Ossica - $O(1.5 ; 2.5 ; 5$ and $10 \mu \mathrm{M})$ for $24 \mathrm{~h}$. Pictures were taken using the $20 x$ objective. 


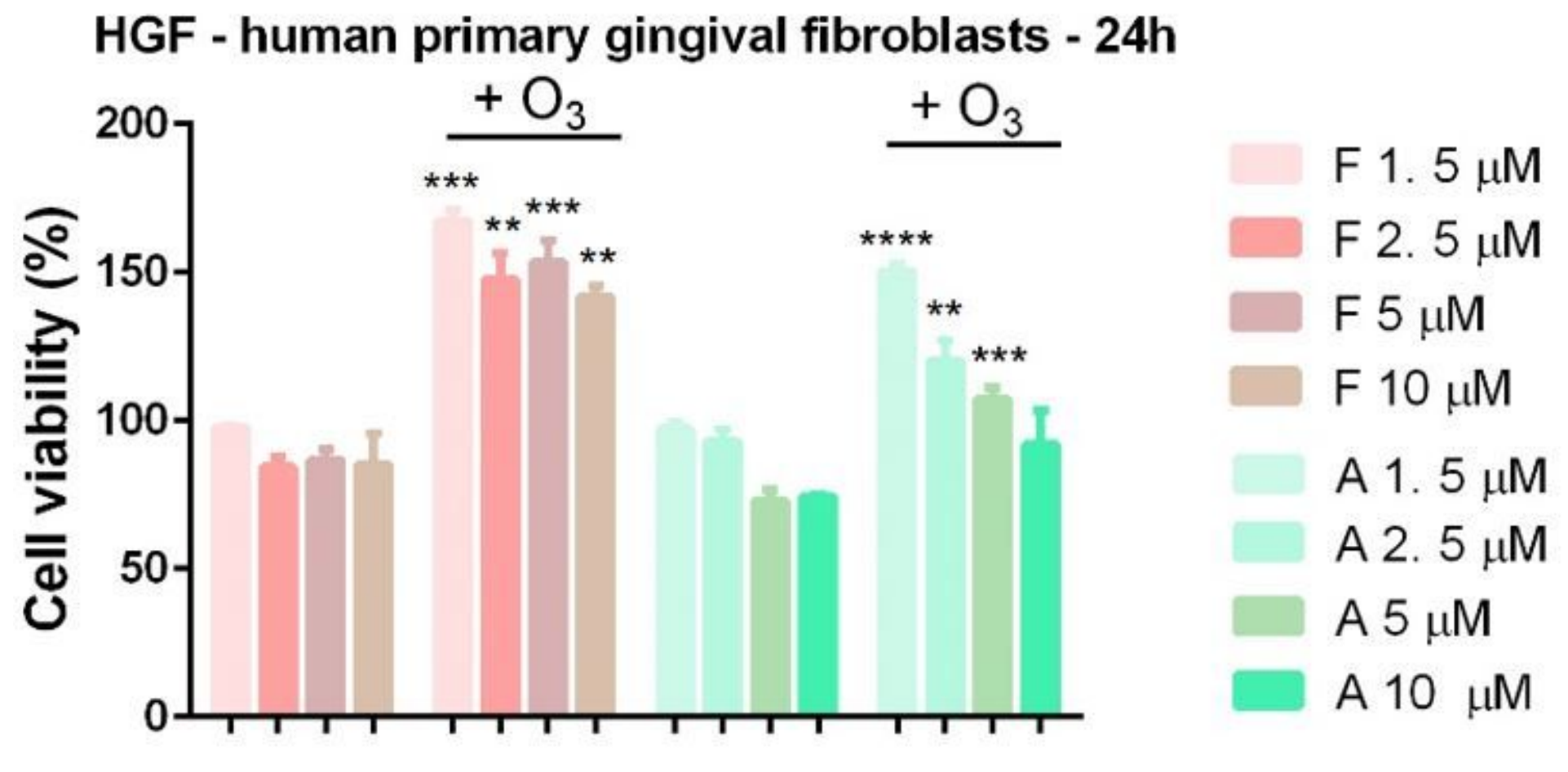

Figure 8

Assessment of ozone (03) solution on HGF - human primary gingival fibroblasts viability stimulated previously with Fosamax $-\mathrm{F}$ and Actonel $-\mathrm{A}(1.5,2.5,5$ and $10 \mu \mathrm{M})$. Data represent the mean values \pm SD of three independent experiments. Unpaired t test with Welch's correction was applied to determine the statistical differences in rapport with 03 unstimulated cells $\left({ }^{\star *} p<0.01,{ }^{* \star *} p<0.001\right.$ and $\left.{ }^{\star * \star *} p<0.0001\right)$. 
$-\mathrm{O}_{3}$

$\mathrm{F} 1.5 \mu \mathrm{M}$

$\mathrm{F} 2.5 \mu \mathrm{M}$

F $5 \mu \mathrm{M}$

$\mathrm{F} 10 \mu \mathrm{M}$
$+\mathrm{O}_{3}$
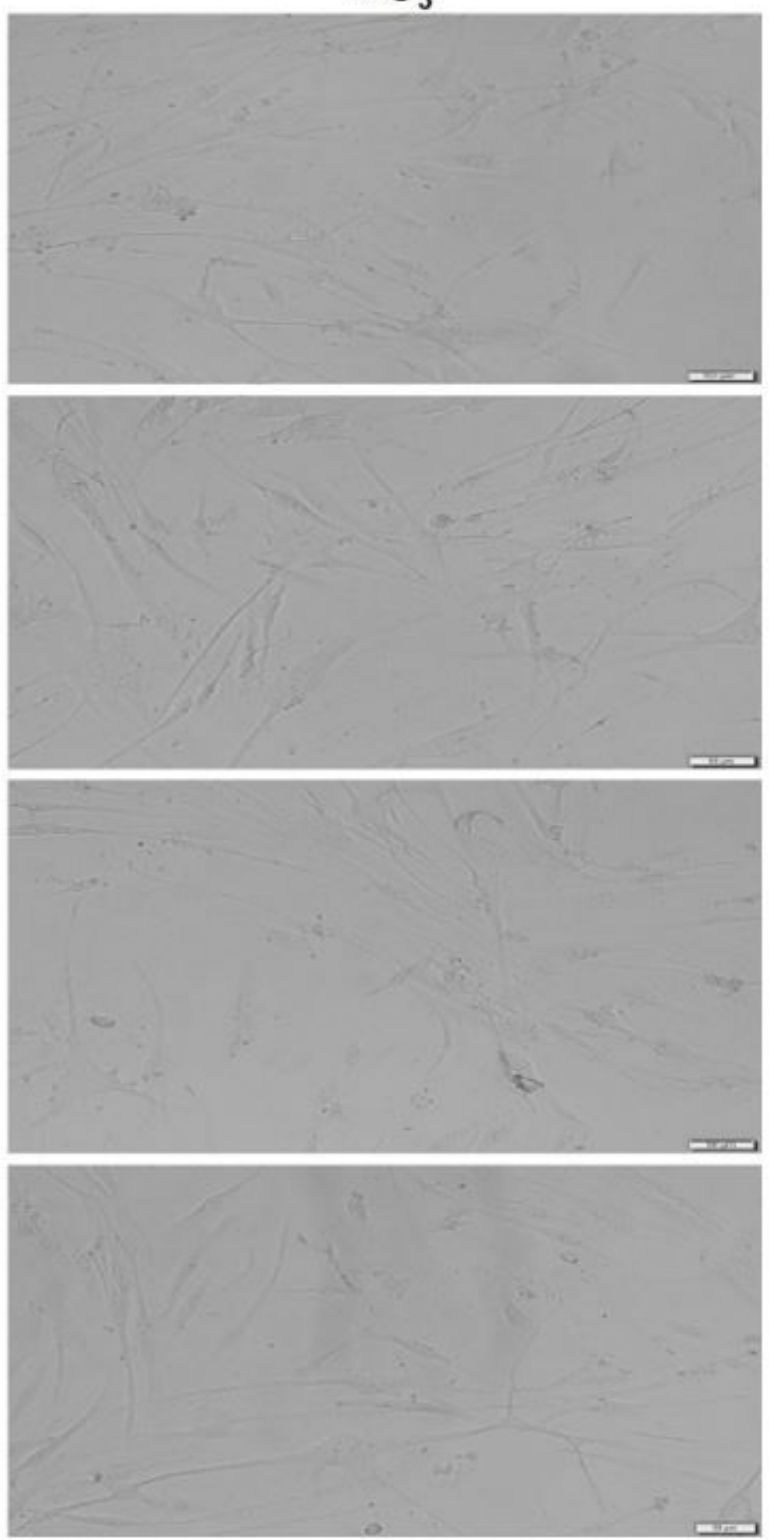

\section{Figure 9}

The aspect of HGF - human primary gingival fibroblasts in culture stimulated with different concentrations of Fosamax - F (1.5; 2.5; 5 and $10 \mu \mathrm{M})$ for $24 \mathrm{~h}$ : without (- 03) and with (+ 03) ozone stimulation. Pictures were taken using the $20 x$ objective at a scale bar of $50 \mu \mathrm{m}$. 
A $1.5 \mu \mathrm{M}$

A $2.5 \mu \mathrm{M}$
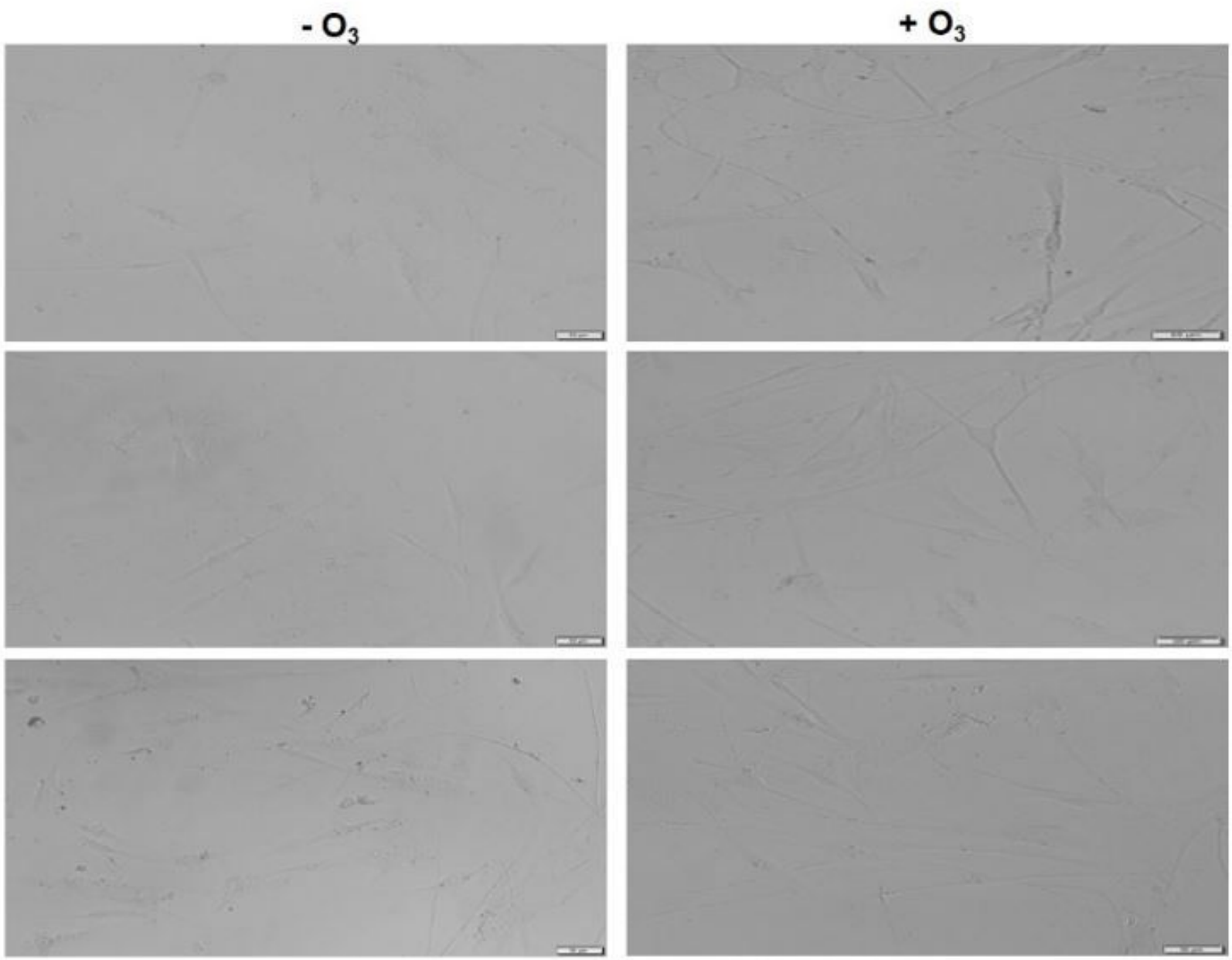

\section{A $5 \mu \mathrm{M}$}

\section{A $10 \mu \mathrm{M}$}
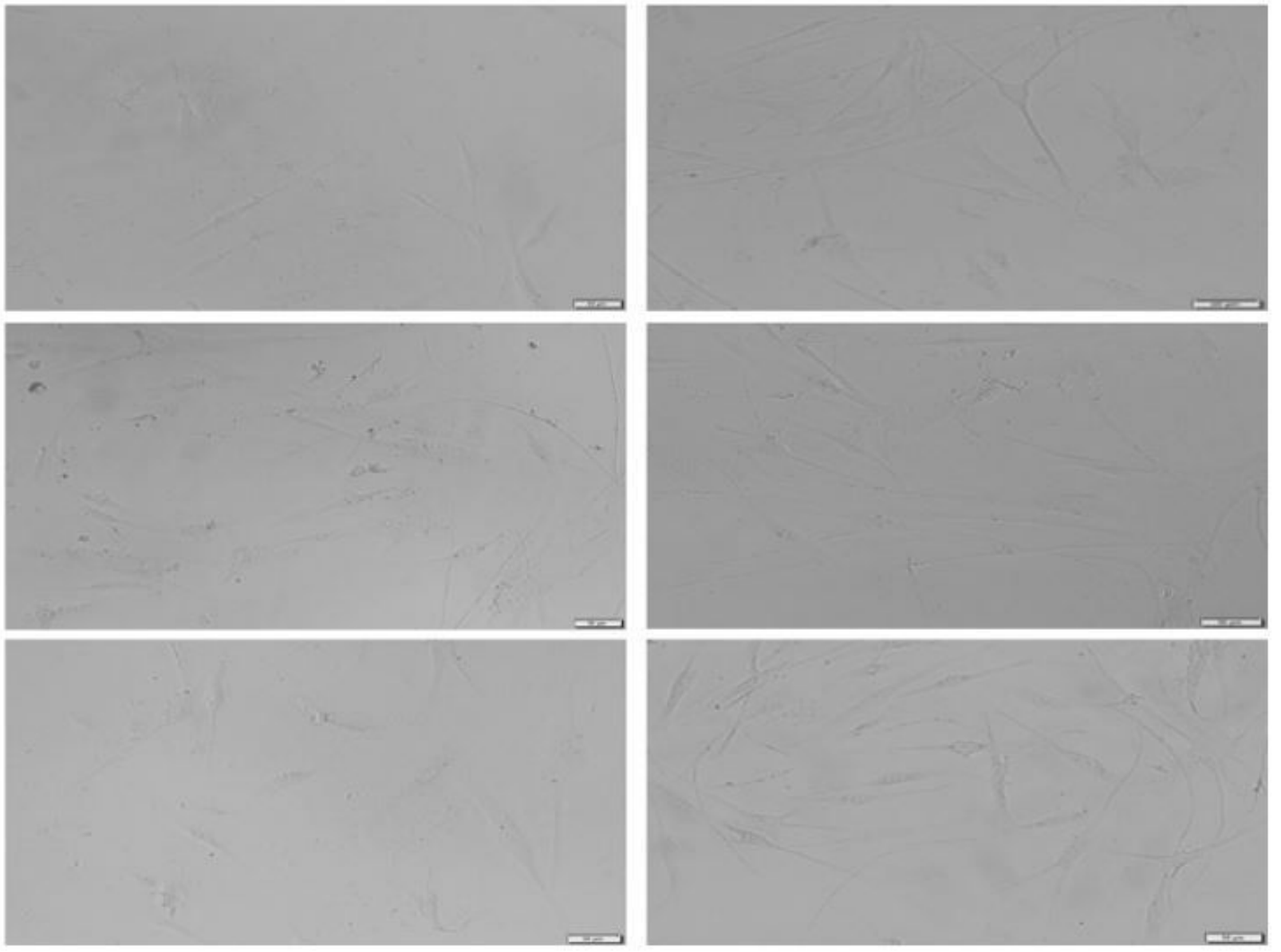

\section{Figure 10}

The aspect of HGF - human primary gingival fibroblasts in culture stimulated with different concentrations of Actonel $-\mathrm{A}(1.5 ; 2.5 ; 5$ and $10 \mu \mathrm{M})$ for $24 \mathrm{~h}$ : without (- 03) and with (+ 03) ozone stimulation. Pictures were taken using the $20 x$ objective at a scale bar of $50 \mu \mathrm{m}$. 